\title{
Chromosome Mosaicism in a Hermaphrodite
}

\author{
C. J. DEWHURST, A. J. N. WARRACK, C. E. BLANK, AUDREY M. BISHOP, \\ and W. B. HESLOP
}

\author{
From the City General Hospital, and The Centre for Human Genetics, Sheffield
}

The chromosome complement in 27 patients with convincing evidence of hermaphroditism has now been investigated. A normal female karyotype (44 autosomes $+\mathrm{XX}$ ) was reported in 17 cases (Bregman, Bregman, Cushner, and Woods, 1963; de Assis, Epps, and Bottura, 1960; Dewhurst, Warrack, and Casey, 1963; German, Bearn, and McGovern, 1962; Gordon, O'Gorman, Dewhurst, and Blank, 1960; Harnden and Armstrong, 1959; Hungerford, Donnelly, Nowell, and Beck, 1959; Merrill and Ramsey, 1963; Overzier, 1963; Root, Eberlein, Briebart, Moorhead, and Mellman, 1964; Rosenberg, Clayton, and Hsu, 1963; Sasaki and Makino, 1960; Solomon and Green, 1963) and a normal male karyotype $(44+\mathrm{XY})$ in 2 (Sandberg, Koepf, Crosswhite, and Hauschka, 1960; A. A. Sandberg, 1963, personal communication; Shearman, Singh, Lee, Hudson, and Ilbery, 1964). Ferguson-Smith, Johnston, and Weinberg (1960) and M. A. Ferguson-Smith (1964, personal communication) reported a patient who appeared to have a mixture of cell types (mosaicism), one cell line apparently having a $44+\mathrm{XX}$ complement and the other a $44+\mathrm{XXX}$ complement. The same authors report a second case with $44+$ XX karyotype in most of the cells examined, though a few cells showed a small chromosome fragment in addition*. Gartler and his colleagues (Gartler, Waxman, and Giblett, 1962; Waxman, Gartler, and Kelley, I962; Giblett, Gartler, and Waxman, 1963) described a $44+\mathrm{XX} / 44+\mathrm{XY}$ mosaic. Grouchy and others (Grouchy, Moullec, Salmon, Josso, Fregal, and Lamy, I964; J. de Grouchy, 1964, personal communication; Brøgger and Aagenaes, 1964), and A. Brøgger (1965, personal communication) described two other hermaphrodites with $44+\mathrm{XX} / 44+\mathrm{XY}$ mosaicism. Three cell lines, $44+\mathrm{XX}, 44+\mathrm{XXY}$, and $44+\mathrm{XXYYY}$,

\footnotetext{
Received March 17, 1965.

* In a previous paper (Blank, Zachary, Bishop, Emery, Dewhurst, and Bond, 1964) we had not included this case since it seemed to us that the diagnosis of hermaphroditism was not conclusive. Further information kindly supplied to us by Dr. Ferguson-Smith now leaves us in no doubt.
}

were observed in a hermaphrodite described by Fraccaro, Taylor, Bodian, and Newns (1962) and 2 cell lines, $44+\mathrm{XX}$ and $44+\mathrm{XXY}$, in that described by Turpin, Lejeune, and Breton (1962) Blank et al. (1964) described a presumptive $4 \dot{4}$ $+\mathrm{XX} / 44+\mathrm{XXYY}$ mosaic.

A $44+\mathrm{XY} / 44+\mathrm{XO}$ mosaic in which there is some histological support for the diagnosis of hermaphroditism has been described by Hirschhorn $\overrightarrow{-}$ Decker, and Cooper (1960).

\section{Case Report}

We describe here a case of a hermaphrodite with $\overrightarrow{0}$ presumptive $44+\mathrm{XX}+$ fragment $/ 44+\mathrm{XO}$ chronas 요 some mosaicism.

Clinical Findings. The patient was first seen by owes of us (C.J.D.) on May I I, 1964, at 14 months of age. Thक child was the fourth of young parents, the 3 older child ren being clinically normal. The sex at birth was though $\mathbb{D}$ to be male, but doubts were soon expressed, and, though registered in the male sex, the child was brought up as girl. A buccal smear taken shortly after birth was chromatin positive, and a provisional diagnosis of the adrenogenital syndrome was made only to be excluded. by the finding of a 17-ketosteroid excretion of $0.2 \mathrm{mg}$ in 24 hours. Shortly afterwards an injection of contrast medium into an apparent urethra outlined a vagina, $\dot{\alpha}$ uterus, and one tube. Further investigation was clearly indicated.

Examination showed a pale, evidently female child The external genitalia (Fig. I) consisted of a moderate $=$ sized phallus with a single opening at its base resemblings the urethra opening in a position of hypospadias. Ars. apparently bifid scrotum contained, on the left side, at gonad which felt like a testis, and the right side was empty. A gonad could not be felt in the groin. The child was admitted for further investigation. A buccal smear was examined and confirmed to be chromatifu positive (see below). The level of 17 -ketosteroid excre? tion was $0.3 \mathrm{mg} . / 24$ hours and that of the 17 -ketogenis steroids $0.45 \mathrm{mg} . / 24$ hours. An examination undes anaesthesia, a laparotomy, and a chromosomal analysis ${ }^{\circ}$ were planned, but the child was found to have a markedo 


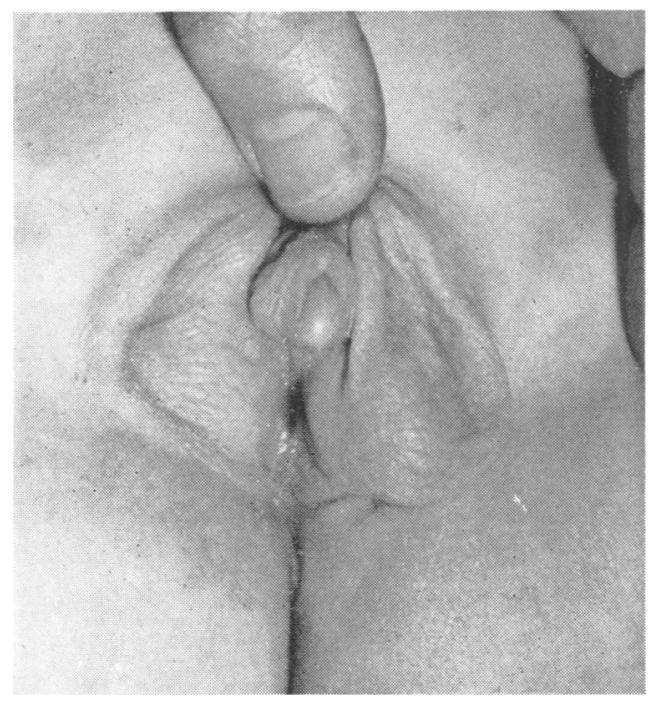

FIg. I. External genitalia at 14 months age.

iron deficiency anaemia so these procedures were postponed until the anaemia was corrected.

On June 9, the abdomen was opened and a unicornuate uterus, a tube, and an ovary were found on the right side of the pelvis. The ovary was less well formed than usual and bore some resemblance to the 'streak' gonad seen in Turner's syndrome, though having more substance than such streaks generally have; it was sufficiently well developed to allow a sliver to be removed from its whole length for biopsy and chromosomal study. The left side of the pelvis contained a fibrous cord, probably the vas deferens, which passed from the bladder base to the internal inguinal ring. The external genitalia were then examined carefully. Only one external opening existed and this led into the bladder. A separate vagina was not identified at this time though previous radiological evidence indicated that one was present. A biopsy was taken from the left gonad which looked like a normal testis. The two gonadal specimens were examined histologically and a small fragment of each together with a piece of skin and a sample of blood were sent for chromosomal study. The detailed findings from all these investigations are set out below.

After considering the evidence carefully it was decided that it was better that the child should continue to live in the female sex in which she had so far been brought up (though not registered). The parents were in complete agreement since they had always regarded their child as a girl.

On June 19, the testis was removed and the tissues on this side fashioned to match the right side, which sufficiently resembled a labium to require no further treatment. The phallus was then reduced in size by a technique previously described (Blank et al., 1964) in which the corpora cavernosa were excised and the glans preserved. A short backward incision from the external perineal opening disclosed the vagina, which was evidently very narrow, lying immediately behind the urethra. It was decided that adequate plastic vaginal enlargement could not be performed at this time and nothing more was done. The parents were firmly told that the child was a normal girl. They were warned that some hormone therapy might be required near to puberty and a plastic vaginal enlargement, probably not involving a major procedure, when marriage was contemplated.

Sex-chromatin and Chromosome Analysis. 45 suitable nuclei in buccal smear preparations were examined for sex chromatin: I4 (31\%) had a single Barr body of normal size. No cell had a nucleus with more than one body. A count of $31 \%$ is within the normal range for an individual with two $\mathrm{X}$ chromosomes.

Chromosome preparations were derived from two peripheral blood cultures, from dermis and from the left gonad. Culture of the right gonad was unsuccessful. Chromosome counts are summarized in the Table. Thirty of the cells with a count of 47 chromosomes were analysed in detail; each had 16 chromosomes in the X-6-12 group and an abnormal small metacentric chromosome (Fig. 2). This centric fragment stained well, did not appear to have satellites, and did not show association with satellited chromosomes. It is the impression of two of us (A.M.B. and M.H.) that this

TABLE

CHROMOSOME COUNTS IN PREPARATIONS DERIVED FROM PATIENT

\begin{tabular}{|c|c|c|c|c|c|c|c|c|c|c|}
\hline \multirow{3}{*}{ Tissue } & \multicolumn{10}{|c|}{ Chromosome Counts } \\
\hline & \multicolumn{2}{|c|}{44} & \multicolumn{2}{|c|}{45} & \multicolumn{2}{|c|}{46} & \multicolumn{2}{|c|}{47} & \multicolumn{2}{|c|}{$4^{8}$} \\
\hline & Counted & Analysed & Counted & Analysed & Counted & Analysed & Counted & Analysed & Counted & Analysed \\
\hline $\begin{array}{l}\text { Blood culture (I) } \\
\text { Blood culture (2) } \\
\text { Skin } \\
\text { Left gonad (testis) }\end{array}$ & $\underline{-}$ & $\overline{-}$ & $\begin{array}{r}2 \\
7 \\
84 \\
47\end{array}$ & $\begin{array}{l}2^{*} \\
7^{*} \\
8^{*} \\
2^{*}\end{array}$ & $\begin{array}{l}5 \\
\mathbf{I} \\
\mathbf{I} \\
\end{array}$ & $\begin{array}{l}\mathbf{s}_{+}^{+} \\
\mathbf{I t} \\
\mathrm{It} \\
\end{array}$ & $\begin{array}{r}22 \\
20 \\
14 \\
3\end{array}$ & $\begin{array}{r}\text { I0 } \\
\text { 10 } \\
7 \pm \\
3 \neq\end{array}$ & $\frac{1}{-}$ & $\underline{-}$ \\
\hline
\end{tabular}

* Presumptive $44+$ XO.

$\dagger$ Three cells appeared to have the fragment chromosome missing; in the remainder various chromsomes were absent.

$\ddagger$ Presumptive $44+\mathrm{XX}+$ centric fragment. 


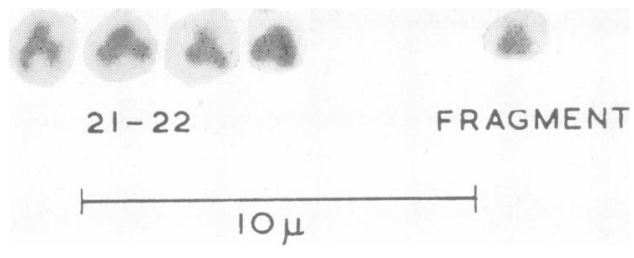

FIG. 2. Chromosomes 2I- $22+$ centric fragment.

centric fragment was more often located at the periphery of the chromosome spread than would be expected by chance. A chromosome with the distinctive morphology of the normal Y chromosome was not apparent. Each of the cells with a count of 45 chromosomes examined in detail had 15 chromosomes in the X-6-12 group. An identifiable $\mathrm{Y}$ chromosome was not apparent, nor was a centric fragment. Although 3 of the 7 cells with a count of 46 chromosomes appeared to have an $\mathrm{XX}$ chromosome complement without the centric fragment the chromosomes in these cells were not well spread. It is probable that a centric fragment was hidden by another chromosome.

It was concluded that two cell lines were present in each of four separate cultures. Detailed analysis of chromosome morphology was compatible with a $44+\mathrm{XX}+$ chromosome fragment $/ \mathbf{4 4}+\mathrm{XO}$ mosaicism.
Histological Examination of Gonads. A biopsy $ه$ taken from the right gonad (Fig. 3) showed a typical $\mathbb{D}$ ovarian stroma but only a few primordial follicles, far $\overparen{D}$ less than would normally be found in a 15-month-old? child. The whole picture was that of an immature $\overrightarrow{\bar{S}}$ embryonic ovary. Material from the left gonad (Fig. 4) consisted of inactive seminiferous tubules. Some of these were present in the tunica suggesting maldevelop- $\frac{\bar{O}}{\bar{N}}$ ment. Few Leydig cells were visible. The maturity of $\frac{D}{T}$ the testis was consistent with the age of the child.

The left gonad was further examined following removal io days later. No tissue other than seminiferous tubules was present.

Blood Group Findings. Blood group studies were $\vec{\omega}$ made on the patient, her father, and her mother. All tests were read microscopically and there was no evidence of mixed field agglutination, indicating that there i was only one red-cell population.

Mother:

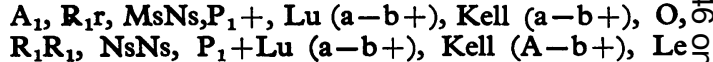

$(\mathrm{a}+\mathrm{b}-), \mathrm{Fy}(\mathrm{a}+), \mathrm{Jk}(\mathrm{a}+\mathrm{b}+), \mathrm{Xg}(\mathrm{a}+)$

Father:

$A_{1}, R_{1} r, M s M s, P_{1}+, L u(a-b+)$, Kell $(a-b+)$,

Le $(a-b+)$, Fy $(a+), J k(a+b+)$, Xg $(a+)$

Patient:

Le $(a+b-)$, Fy $(a+), J k(a+b+), X g(a+)$

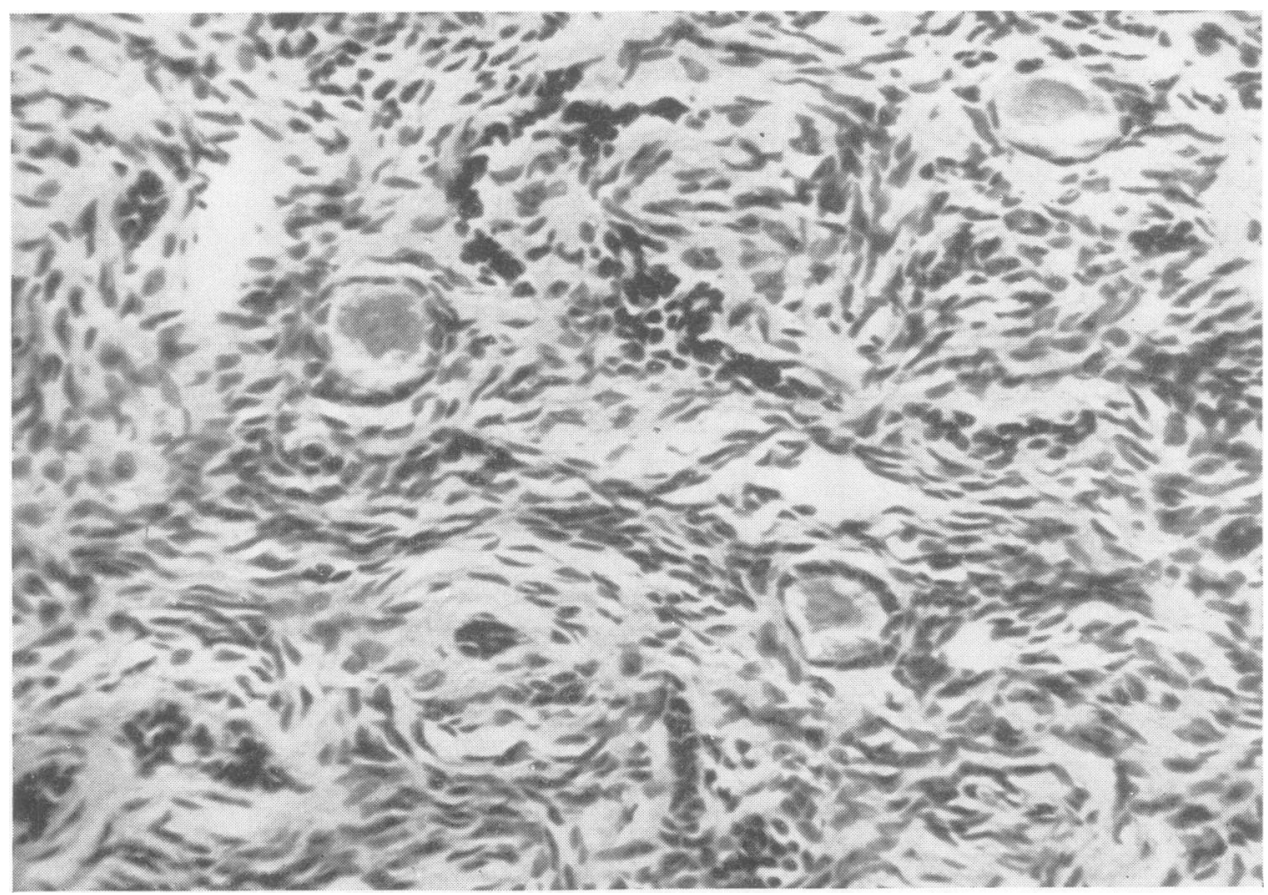

FIG. 3. Biopsy of right gonad showing ovarian stroma and very few primordial follicles. ( $\times 330)$. 


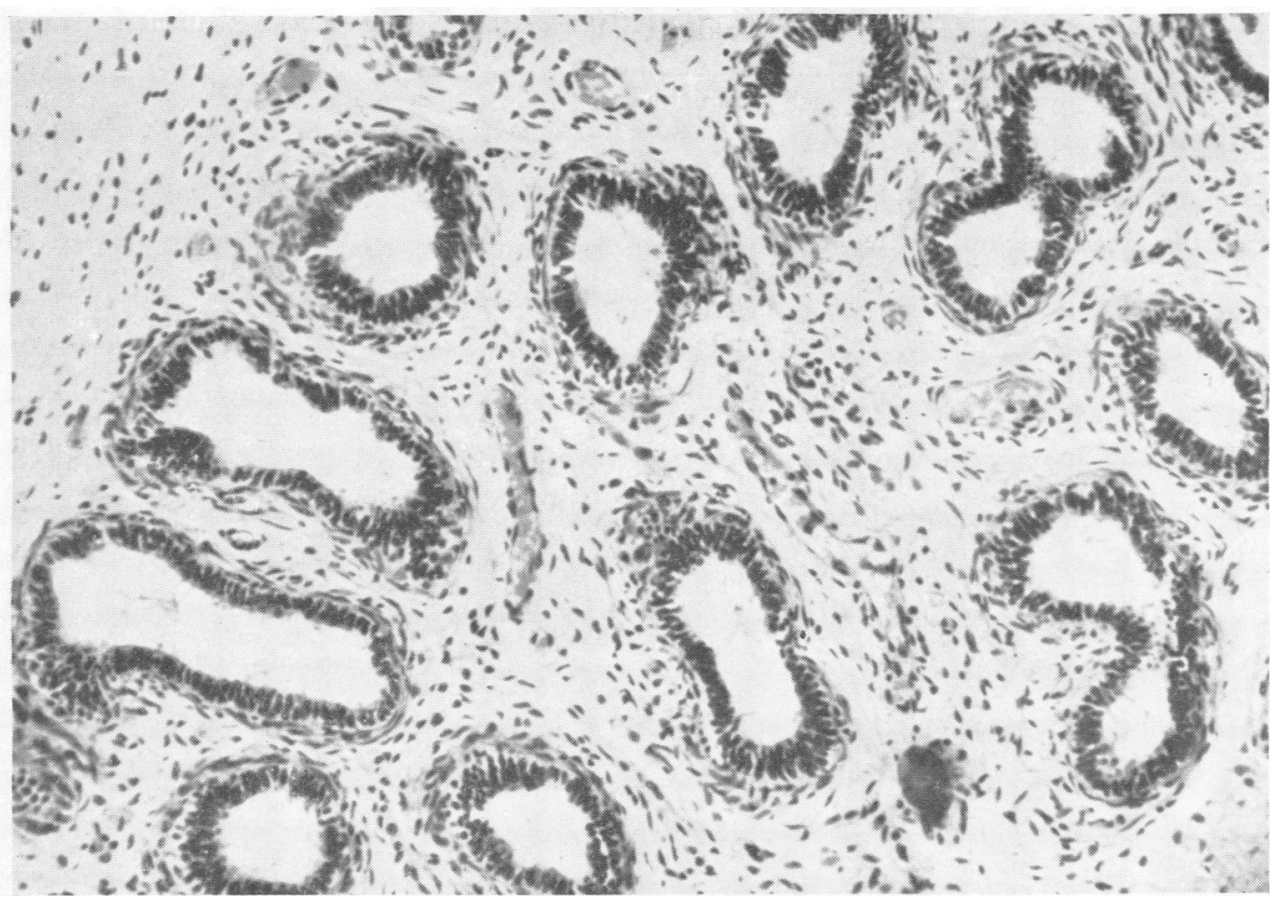

FIG. 4. Biopsy of left gonad showing seminiferous tubules; Leydig cells are not clearly identifiable. ( $x$ 208.)

\section{Discussion}

It is our belief (Gordon and Dewhurst, 1962; Dewhurst and Gordon, 1963), based upon the earlier work of Wilkins and his colleagues (Hampson, 1955; Money, Hampson, and Hampson, 1955a, b; Wilkins, 1960), that in children of doubtful sex the best results are obtained by full investigation during the first year of life followed by a most careful decision on the more appropriate sex of rearing. This decision may then be underlined by suitable plastic surgical procedures and sometimes by hormone therapy as well. In this case the child was first seen at the age of I4 months. A full investigation was undertaken as soon as possible and a diagnosis of hermaphroditism was established.

Probably the most important single factor in deciding the more appropriate sex of rearing of a hermaphrodite baby is the functional possibility of the external genitalia. In this case plastic surgical treatment could have made the genitalia conform to either sex and some other criteria were required to permit this decision to be made. The necessary plastic surgery was simpler if the child was to be female, but a more important consideration seemed to be that, though the child was not yet old enough to have formed any firm affinities with either sex, the parents had become accustomed to regarding her as a girl. To continue the female sex involved no emotional change for them even though legal re-registration was required.

The nature of the gonads in cases of hermaphroditism has seemed to us to be important only because the unwanted gonadal tissue requires to be removed to prevent later heterosexual manifestations. In the present case, at the time of the investigation, the testis appeared the more normal gonad, but we were not disposed to allow this to influence our choice as it seemed much less important than the other consideration mentioned above. The poor development of the ovary however makes it likely that oestrogen therapy will be desirable when the child approaches puberty; this cannot be considered a serious disadvantage.

We believe it important in this kind of case to remove all external evidence of maleness so that nothing shall interfere with the parents' view of their child as being completely normal. Accordingly the testis was removed and the clitoris reduced in size. It was then apparent that the vaginal 
narrowing was greater than could properly be dealt with by a plastic enlargement at that time and it is intended to review this aspect of the case when the child is much older.

The appearance of the ovary, both macroscopic and microscopic, was most interesting. Macroscopically this gland resembled the 'streak' gonads found at operation in $44+\mathrm{XO}$ patients of Turner's syndrome but had more substance to it. Histological examination showed the presence of far fewer primary follicles than are normally found in young children.

Although ovarian follicles are not seen in the streak gonads of Turner's syndrome, it must be remembered that the gonads of these patients are not examined until after the normal age of puberty. It might be suggested that follicles may have been present at an earlier age. If indeed this is the case, then poor ovarian development in our patient may be referred to the presence of the $44+\mathrm{XO}$ cell line. Alternatively the ova in our patient may be related to the presence of the $44+\mathrm{XX}+$ fragment cell line.

The precise nature of the chromosome fragment here cannot be determined. It is tempting to consider it a fragment of a $\mathrm{Y}$ and to relate the testicular tissue to the $44+\mathrm{XX}+$ fragment (? Y) cell line.

We are indebted to the late Dr. I. Dunsford, National Blood Transfusion Service, Regional Transfusion Centre, Sheffield, for a report on the blood group investigation carried out on the patient and her parents.

\section{REPERENCES}

Blank, C. E., Zachary, R. B., Bishop, A. M., Emery, J. L., Dewhurst, C. J., and Bond, J. H. (1964). Chromosome mosaicism in a hermaphrodite. Brit. med. F., 2, 90.

Bregman, R. U., Bregman, E. T., Cushner, G. B., and Woods, F. M. (1963). Chromosomal analysis, nuclear sex, clinical and endocrine studies of a true hermaphrodite. F. Urol. (Baltimore), 89, 475 .

Brøgger, A., and Aagenaes, O. (1964). Role of $\mathrm{Y}$ chromosome in development of testicular structures. Lancet, 2, 259.

de Assis, L. M., Epps, D. R., and Bottura, C. (1960). Chromosomal constitution and nuclear sex of a true hermaphrodite. ibid., 2, 129.

Dewhurst, C. J., and Gordon, R. R. (1963). Change of sex. ibid., 2, 1213.

, Warrack, A. J. N., and Casey, M. D. (1963). An XX hermaphrodite with male social sex. Brit. med. f., 2, 221.

Ferguson-Smith, M. A., Johnston, A. W., and Weinberg, A. N, (I960). The chromosome complement in true hermaphroditism. Lancet, 2, 126.
Fraccaro, M., Taylor, A. I., Bodian, M., and Newns, G. H. (1962) A human intersex (true hermaphrodite) with XX/XXY/XXYYY sex chromosomes. Cytogenetics (Basel), I, ro'4.

Gartler, S. M., Waxman, S. H., and Giblett, E. (1962). An XX/XY. human hermaphrodite resulting from double fertilization Proc. nat. Acad. Sci. (Wash.), 48, 332.

German, J. L., III, Bearn, A. G., and McGovern, J. H. (I962) Chromosomal studies of three hermaphrodities. Amer. $f$. Med. 33, 83.

Giblett, E. R., Gartler, S. M., and Waxman, S. H. (1963). Blooks group studies on the family of an $\mathrm{XX} / \mathrm{XY}$ hermaphrodite with generalized tissue mosaicism. Amer. F. hum. Genet., 15, 62.

Gordon, R. R., and Dewhurst, C. J. (1962). Ambiguous sex in the newborn. Lancet, 2,872 .

, O'Gorman, F. J. P., Dewhurst, C. J., and Blank, C. E. (1960) U Chromosome count in a hermaphrodite with some features of Klinefelter's syndrome. ibid., 2, 736.

Grouchy, J. de, Moullec, J., Salmon, C., Josso, N., Fregal, J., and Lamy, M. (1964). Hermaphrodisme avec caryotype XX-XY io étdere de génétique d'un cas. Ann. Génét., 7, 25.

Hampson, J. G. (I955). Hermaphroditism genital appearance, rearing and eroticism in hyperadrenocorticism. Bull. fohns Hopk Hosp., 96, 265.

Harnden, D. G., and Armstrong, C. N. (1959). The chromosomes? of a true hermaphrodite. Brit. med. F., 2, 1287.

Hirschhorn, K., Decker, W. H., and Cooper, H. L. (1960). Human intersex with chromosome mosaicism of the type XY/XO. New Engl. F. Med., 263, 1044 .

Hungerford, D. A., Donnelly, A. J., Nowell, P. C., and Beck, S.(1959). The chromosome constitution of a human phenotypic intersex. Amer. F. hum. Genet., 11, 215.

Merrill, J. A., and Ramsey, J. E. (1963). True hermaphroditism:® report of a case and review of the literature. Obstet. and Gynec., 22, 505 .

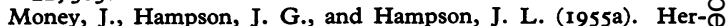
maphroditism; recommendations concerning assignment of sex, change of sex, and psychological management. Bull. fohns Hopk. $\vec{\bullet}$ Hosp., 97, 284.

,-- and - (1955b). An examination of some basic sexfilc concepts: the evidence of human hermaphroditism. ibid.,

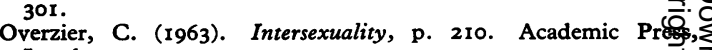
London.

Root, A. W., Eberlein, W. R., Briebart, S., Moorhead, P. S., and Mellman, W. J. (1964). Chromosomal analysis of multiple tissues from a true hermaphrodite. F. clin. Endocr., 24, 467.

Rosenberg, H. S., Clayton, G. W., and Hsu, T. C. (1963). Familial true hermaphrodism. ibid., 23, 203.

Sandberg, A. A., Koepf, G. F., Crosswhite, L. H., and Hauschka, T. S. (1960). The chromosomal constitution of human marrow in various developmental and blood disorders. Amer. f. hum.? Genet., 12, 231 .

Sasaki, M., and Makino, S. (1960). The chromosomal constitutionof a human hermaphrodite. Tex. Rep. Biol. Med., 18, 493.

Shearman, R. P., Singh, S., Lee, C. W. G., Hudson, B., and Ilbery P. L. T. (1964). Clinical, hormonal, and cytogenic findings in $a_{0}^{-}$ true hermaphrodite. F. Obstet. Gynaec. Brit. Cwlth, 71, 627.

Solomon, I. L., and Green, O. C. (1963). The chromosome count.in a true hermaphrodite. F. Pediat., 63, 333.

Turpin, R., Lejeune, J., and Breton, A. (I962). Hermaphrodisme XX/XXY. C.R. Acad. Sci. (Paris), 255, 3088.

Waxman, S. H., Gartler, S. M., and Kelley, V. C. (1962). Apparento masculinization of the female fetus, diagnosed as true hermaphrodism by chromosomal studies. F. Pediat., 60, 540 .

Wilkins, L. (1960). Abnormalities of sex differentiation. Pediatrics, 26, 846 . 